\title{
UTILIZATION OF IMMUNOMAGNETIC SEPARATION FOR DETECTION OF SALMONELLA IN RAW BROILER PARTS
}

\author{
Aldemir Reginato Ribeiro; Vladimir Pinheiro do Nascimento*; Martha Oliveira Cardoso; \\ Luciana Ruschel dos Santos; Silvio Luís da Silveira Rocha
} Centro de Diagnóstico e Pesquisa em Patologia Aviária, Faculdade de Veterinária da Universidade Federal do Rio Grande do
Sul, Porto Alegre, RS, Brasil

Submitted: November 08, 2000; Returned to authors for corrections: April 03, 2001; Approved: December 05, 2002.

\begin{abstract}
This study was conducted aiming to compare the conventional microbiological method to detect Salmonella in broiler parts with the Immunomagnetic Separation method (IMS) followed by plate isolation and also the IMS associated with Rappaport-Vassiliadis broth (RV). The IMS was performed following a pre- enrichment step in buffered peptone water. Sixty-one samples (raw broiler parts) were tested and the results showed that the use of the IMS method alone allowed the isolation of Salmonella in 9 of the tested samples, while the association IMS/ $\mathrm{RV}$ detected the agent in 30 samples. The conventional microbiological method was able to isolate the agent in 25 opportunities. These results allowed to conclude that the IMS/RV association presented an increased sensitivity and permitted a better isolation of Salmonella. The conclusion was that other means of isolation, in particular those which do not interfere with the growth of bead bounded Salmonella, should be searched.
\end{abstract}

Key words: Immunomagnetic separation, Salmonella, raw broiler parts

\section{INTRODUCTION}

The conventional microbiological method for the detection of Salmonella in broiler chicken carcasses is the one recommended by the Brazilian Ministry of Agriculture, which is carried out in four steps: pre-enrichment, selective enrichment, agar plating and biochemical and antigenical characterization (2).

Because of market demands, Salmonella detection analyses are becoming more frequent and being performed in growing number of samples. As a consequence, a great deal of effort have been done to increase the sensitivity of the diagnostic process and to reduce the time spent to obtain a result.

A review by Blackburn (1) gathered information about some of the methods, such as: rapid culture techniques (shortened liquid enrichment, selective enrichment, serology), metabolism measurements (conductance, radiometry), immunoassays (flurescent-antibody staining, enzyme immunoassays and immunosensors), bacteriophages, gene probes and separation and concentration techniques.

The immunomagnetic separation is included among the separation and concentration techniques, having the ability to separate the target bacteria from other competitive microorganisms. Further cultivation can be done on agar plates or in broth $(3,9)$.

This experiment aimed to compare results obtained using the conventional microbiological method recommended by the Brazilian Ministry of Agriculture for the isolation of Salmonella (2) with those obtained using the immunomagnetic separation and the immunomagnetic separation combined with the Rappaport-Vassiliadis broth.

\section{MATERIALS AND METHODS}

\section{Samples}

Sixty-one broiler chicken parts (wings, whole legs, boneless breasts and backs) were analysed.

\footnotetext{
* Corresponding author. Mailing address: Av. Bento Gonçalves, 8824. 91540-000. Porto Alegre, RS, Brasil. Fax: (+5551) 3319-1062. E-mail: vladimir@ufrgs.br
} 


\section{Conventional Microbiological Method}

The conventional microbiological method was used according to the technique recommended by the Brazilian Ministry of Agriculture for the detection of Salmonella (2). Xilose lysine tergitol 4 agar (XLT4) (Difco, Detroit, MI, USA) was also used as solid medium for isolation of the pathogen.

Twenty-five grams of skin and muscle, collected under asseptic conditions, were taken from each broiler and homogenized in 225 $\mathrm{mL}$ of Buffered Peptone Water (BPW) (Merck AG, Darmstadt, Germany), and incubated at $37^{\circ} \mathrm{C}$ for $24 \mathrm{~h}$ (pre-enrichment). After this, 1 and $0.1 \mathrm{~mL}$ of the pre-enrichment broth were subcultured in $9 \mathrm{~mL}$ of tetrathionate broth (Merck) and 9,9 mL of RappaportVassiliadis broth (Merck), respectively, and incubated at $41^{\circ} \mathrm{C}$ (selective enrichment). After $24 \mathrm{~h}$, the selective enrichment cultures were streaked on XLT4 and Rambach (Merck) agar plates and incubated for $24 \mathrm{~h}$ at $37^{\circ} \mathrm{C}$. Typical colonies were identified by biochemical and serological tests. Complete antigenic characterization and serovar identification was performed by the Oswaldo Cruz Institute Foundation at Rio de Janeiro.

\section{Immunomagnetic Separation}

Dynabeads anti-Salmonella (Dynal, Oslo, Norway) conjugates were used. The immunomagnetic separation was accomplished starting from the conventional microbiological method's preenrichment broth, from which $1 \mathrm{~mL}$ was transferred to a tube containing $9 \mathrm{~mL}$ of sterile phosphate buffered saline (PBS), $\mathrm{pH}$ 7.4, from which $1 \mathrm{~mL}$ was subsequently transferred to an Eppendorf tube containing $20 \mu \mathrm{L}$ of anti-Salmonella Dynabeads. These tubes were incubated with gentle mixing at room temperature for 15 minutes. They were then placed in a magnetic particle concentrator (MPC $®-M$, Dynal AS, Norway) for 5 minutes. The supernatant fluid was removed with the aid of Pasteur pipette. Then the beads were ressuspended in $1 \mathrm{~mL}$ of PBS containing $0.05 \%$ of Tween 20 and the tubes were placed back in the magnetic particle concentrator. The process previously described was repeated for a second time, after which the beads were again ressuspended in $100 \mu \mathrm{L}$ of PBS. Aliquots $(33 \mu \mathrm{L})$ were distributed on Rambach and XLT4 agar plates, which were incubated for $24 \mathrm{~h}$ at $37^{\circ} \mathrm{C}$, and also transferred to tubes with Rappaport-Vassiliadis broth, which were incubated for $20-24 \mathrm{~h}$ at $41^{\circ} \mathrm{C}$ and then streaked on Rambach and XLT4 agar plates. After this step, the procedure was the same used in the conventional microbiological method.

\section{RESULTS AND DISCUSSION}

According to the data presented in Table 1, it was observed that using the conventional microbiological method (method A) Salmonella was isolated in 25 out of 61 samples, while using the immunomagnetic separation $(\operatorname{method} B)$ the agent was detected in only 9 samples.

The IMS performance differs from that obtained by other authors. Mansfield and Forsythe (7) and Molla et al. (8) stated that this technique had the same efficiency as the conventional microbiological method. On the other hand, Cudjoe et al. (5) and Coleman et al. (3) affirmed that the IMS was superior to the conventional microbiological method.

However, the results obtained in the present experiment are in agreement with the ones published by Coleman et al. (4) and Ripabelli et al. (11), which reported a poor performance of the IMS method in detecting Salmonella from, respectively, naturally contaminated raw sausages and poultry samples. The use of highly selective plating media can be one of the causes (4), since the selection pressure can make the growth of bacteria linked to the beads more difficult (5).

Perhaps this explains the poor performance of the IMS experienced in this work, since when, after the IMS, one aliquot of each sample was cultivated in Rappaport-Vassiliadis broth and then streaked on the agar plate, Salmonella isolation was obtained in 30 out of 61 samples (Table 1), which means that the bacteria could be linked to the beads and would not be able to develop effectively on the agar plate used.

The results obtained with this double enrichment process (IMS and Rappaport-Vassiliadis broth), according to Table 1, confirms Coleman et al. (4) statements, who reported an increase in sensitivity after the use of a similar process.

This conclusion is reinforced when false-negative results are analysed (Table 1). The crossing of data from this table indicate that the isolation of Salmonella occurred in 32 different samples, which was considered the total number of positive samples. In this way, there were 7 samples with false-negative results when the conventional microbiological method was used, while 23 false-negative results were detected when the IMS alone was used. On the other hand, this result occurred in only two samples when the association of IMS and RappaportVassiliadis broth was used.

The double enrichment process also resulted in a better isolation of Salmonella colonies on selective agar plates, which in many occasions were the only type of colony present.

The results obtained in this experiment allow for an extrapolation on what is referred as the possible benefits of the use of the IMS/RV method in a wider sampling plan for poultry

Table 1. Isolation of Salmonella by methods A, B and C.

\begin{tabular}{lccc}
\hline & Method A* & Method B $* *$ & Method C $* * *$ \\
\hline Positive & 25 & 9 & 30 \\
Negative & 36 & 52 & 31 \\
False Negative & 7 & 23 & 2 \\
\hline Total & 61 & 61 & 61 \\
\hline
\end{tabular}

* Method A: conventional microbiological method;

** Method B: immunomagnetic separation;

*** Method C: immunomagnetic separation combined with the Rappaport-Vassiliadis broth. 
Table 2. Serovars of Salmonella isolated by each method.

\begin{tabular}{lccc}
\hline \multicolumn{1}{c}{ Serovar } & Method A* & Method B** & Method C*** \\
\hline $\begin{array}{l}\text { Salmonella } \\
\text { Enteritidis }\end{array}$ & 21 & 7 & 21 \\
$\begin{array}{l}\text { Salmonella } \\
\text { Hadar }\end{array}$ & 3 & 2 & 3 \\
$\begin{array}{l}\text { Salmonella } \\
\text { Typhimurium }\end{array}$ & 1 & - & 7 \\
\hline
\end{tabular}

* Method A: conventional microbiological method;

** Method B: immunomagnetic separation;

*** Method C: immunomagnetic separation combined with the Rappaport-Vassiliadis broth.

meat. In a given plan foreseeing a number of collected samples (n) of 60, with an expected contamination (p) of $2 \%$ and a level of tolerance (c) equal to zero, a shipment of poultry meat would be treated as suspicious if the pathogen is found in any of the tested samples (6). In this case, the possibility of acceptance of a positive shipment (false negative) is relatively high (ca. 30\%), which means that only 2 in every 3 positive samples would be correctly rejected. The use of the referred method substantially decreased the number of false-negatives from 7 to 2 out of 61 samples, indicating that such sampling plan can be significantly improved. Further testing can also help the establishment of sampling plans which would meet acceptance demands as well as reducing the costs involved in the process of quality verification of shipments of animal origin products.

Regarding the serovars (Table 2), Salmonella Enteritidis was the most frequently isolated one (21 times by methods A and C and 7 times by method B). Salmonella Hadar was isolated in 3 opportunities by methods $\mathrm{A}$ and $\mathrm{C}$ and in 2 occasions by method B, while Salmonella Typhimurium was isolated only once by method A and in 7 instances by method C.

The fact that Salmonella Enteritidis was the predominant serovar reinforces the worldwide concern about its occurrence, especially in terms of its role as an important contaminant of retail chicken products (10) and frozen broiler chickens (12).

Therefore, alternative procedures to reduce the contamination of the final product by Salmonella should continue to be searched for, as well as improved and more reliable diagnostic methods or their associations should be implemented, decreasing the possibilities of false negative results.

\section{ACKNOWLEDGEMENTS}

The authors wish to acknowledge Dulce Maria Tocchetto Schuch, Maristela Lovato Flores, Rosicler da Luz and Eliane Moura Fallavina dos Reis for their technical assistance and the National Council for Scientific and Technological Development (CNPq) for financial support.

\section{RESUMO}

\section{Utilização da separação imunomagnética na detecção de Salmonella em cortes de frango}

Este trabalho foi conduzido com o objetivo de comparar o método microbiológico convencional para detecção de Salmonella em partes de frango, com o método de separação imunomagnética (IMS) e de separação imunomagnética associada ao caldo Rappaport-Vassiliadis (RV). A IMS foi realizada a partir do caldo de pré-enriquecimento. Os resultados obtidos nas 61 amostras (partes de frango) testadas indicam que a separação imunomagnética seguida de plaqueamento em meio sólido isolou o agente em 9 das 61 amostras, enquanto a associação IMS/RV isolou o agente em 30 das 61 amostras e o método microbiológico convencional foi capaz de isolar a bactéria em 25 amostras. Através destes resultados, conclui-se que a combinação IMS/RV aumenta a sensibilidade do processo. Outra conclusão possível foi de que deve-se buscar outros meios de isolamento e seleção de colônias (em ágar) que não interfiram no crescimento das salmonelas ligadas aos "beads".

Palavras-chave: Separação Imunomagnética, Salmonella, partes de frango.

\section{REFERENCES}

1. Blackburn, C.W. Rapid and Alternative Methods for the Detection of Salmonellae in Foods. Review. J. Appl. Bacteriol., 75: 192-214, 1993.

2. Brasil. Ministério da Agricultura do Abastecimento e Reforma Agrária/ Secretaria de Defesa Agropecuária. Método Analítico de Carcaças de Aves e Pesquisa de Salmonella. Diário Oficial da União. Brasília. Portaria SDS no 08 de 23 de janeiro de 1995. p.11182-11188. 27 de janeiro de 1995. Seção I.

3. Coleman, D.J.; Chick, K.J.; Nye, K.E. An evaluation of immunomagnetic separation for the detection of Salmonellae in raw chicken carcasses. Lett. Appl. Microbiol., 21 (3): 152-154, 1995a.

4. Coleman, D.J.; Chick, K.J.; Nye, K.E.; Gagg, C.M. Comparison of immunomagnetic separation plus conventional enrichment with Salmonella culture in the examination of raw sausages. Lett. Appl. Microbiol., 21(4): 249-251, 1995 b.

5. Cudjoe, K.S.; Krona, R.; Olsen, E. IMS: the new selective enrichment technique for detecting Salmonella in foods. Int. J. Food Microbiol., 23: 159-165, 1994.

6. ICMSF. Appropriate Sampling Plans. In: Microorganisms in Food 2 , Sampling in Microbiological Analysis: Principles and Specific Applications. Toronto: University of Toronto Press, 1978, p.19-31.

7. Mansfield, L.; Forsythe, S.J. Immunomagnetic separation: an alternative to enrichment broths for Salmonella detection. Lett. Appl. Microbiol., 16: 122-125, 1993.

8. Molla, B.; Kleer, J.; Sinell, H.J. Detection of Salmonella in foods by immunomagnetic separation. Arch. Lebensm., 45: 97-120, 1994.

9. Olsvik, N.; Popovic, T.; Skjeerve, E.; Cudjoe, K.S.; Hornes, E.; Ugelstad, J.; Uhlén, M. Magnetic Separation Techniques in Diagnostic Microbiology. Clin. Microbiol. Rev., 7 (1): 43-54, 1994.

10. Plummer, R.A.S.; Blissett, S.J.; Dodd, C.E.R. Salmonella Contamination of Retail Chicken Products Sold in the UK. J. Food Prot., 58(8): 843-846, 1995.

11. Ripabelli, G.; Sanmarco, M.L.; Ruberto, A.; Iannitto, G.; Grasso, G.M. Immunomagnetic separation and conventional culture procedure for the detection of naturally occurring Salmonella in raw pork sausages and chicken meat. Lett. Appl. Microbiol., 24: 493-497, 1997.

12. Santos, D.M.S.; Berchieri Jr., A.; Fernandes, S.A.; Tavechio, A.T.; Amaral, L.A. Salmonella em carcaças de frango congelados. Pesq. Vet. Bras., 20(1): 39-42, 2000. 